\title{
A FOGYATÉKKAL ÉLŐ EMBEREK ELUTASÍTÁSÁNAK ÉS ELFOGADÁSÁNAK TÖRTÉNETE NAPJAINKIG ÉS HELYZETÜK A MAI OKTATÁSI RENDSZERBEN
}

Szerző:

Erdei Norbert

Móra Ferenc Általános Iskola

Szerző e-mail címe:

erdei.norbert.70@gmail.com

\section{Lektorok:}

Keresztesi Katalin

Debreceni Egyetem

Lenténé Puskás Andrea

Debreceni Egyetem

Mező Katalin

Debreceni Egyetem

Nemes Magdolna

Debreceni Egyetem

Erdei Norbert (2016): A fogyatékkal élő emberek elutasításának és elfogadásának története napjainkig és helyzetük a mai oktatási rendszerben. Különleges Bánásmód, II. évf. 2016/3. szám, 41-49. DOI 10.18458/KB.2016.3.41

\begin{abstract}
Absztrakt
Jelen tanulmány célja, hogy áttekintse a fogyatékkal élő emberek elfogadásának és elutasitásának a történetét az ókortól a XXI. századik Különösen a sajátos nevelési igényü tanulók helyzetét vizsgálja 21 tanulmány összegzése alapján. Pedagógusok vitáznak, a kérdés azonban még mindig megválaszolatlan marad: melyik oktatási forma lenne kedvezöbb számukra: az integrált, vagy a szegregált?
\end{abstract}

Kulcsszavak: fogyatékkal élők, történet, sajátos nevelési igény

Diszciplinák: pedagógia, gyógypedagógia

\begin{abstract}
HISTORY OF REJECTION AND ACCEPTANCE OF PEOPLE LIVING WITH DISABILITES UP TO THE PRESENT DAY AND THEIR SITUATION IN THE EDUCATION SYSTEM

The aim of this study is to make a review on people with disabilities in terms of acceptance and rejection from the antiquity till the 21th century. It also focuses on the students with special educational needs based on 21 empirical studies. Teachers have debates, but the question still remains unanswered: which educational form would be better for this group of students, the integrative or the segregative?
\end{abstract}

Keywords: people with disabilities, history, students with special educational needs

Disciplines: pedagogy, special education 
A fogyatékosság mindig is jelen volt az állatvilágban és természetesen az emberek között is. Az állati populációkban azonban az esetek többségében az adott egyed életével összeegyezhetetlen volt. Könnyebben vált a ragadozók áldozatává, nehezebben jutott táplálékhoz, esetleg a saját fajtársai üzték el, illetve ették meg. A legszerencsésebb esetben, ha meg is érte a szaporodóképes kort, párt nem talált, a szaporodás elmaradt, így az ő egyedi génállománya mindörökre eltünt. Szelekciós nyomás hat a sérült egyedre, nincsen lehetősége szaporodni. „A Természet védi az elkorcsosulástól a Természetet, egész bőkezüségével és maradéktalan szigorúságával. Aki fázik: menjen délre, akinek melege van: menjen északra. Aki éhezik, keressen, harcoljon, vándoroljon oda, ahol van élelem. Alkalmazkodjék ahhoz, ami van, vagy - pusztuljon. Írja Fekete István a természet titkait gyönyörüen ábrázoló író müvében a „Téli berek"-ben. (Fekete, 1959)

A másság, a fogyatékosság elfogadása ősidők óta létezik a társadalomban. (Vidáné, 2013) Az ember történelme során az eltérö kultúrák eltérően reagáltak a fogyatékkal élö emberekre. Az esetek jelentős részében a sérült ember elutasításának, mind befogadásának tehát biológiai alapjai vannak. Az ókori Egyiptomban a törpe növésü embereket tisztelték és pozitív tulajdonságokkal ruházták fel, mint például Szenebet - a törpét, aki az udvari szövőmühely vezetője, de emellett Kheopsz és Dzsefré fáraók piramisainak a papi rangjának is birtokosa volt. (Kákosy és Varga, 1970) Az ókori Görögországban ezzel ellentétesen vélekedtek a fogyatékos emberekről. Az akkori ideál az egészséges ember volt. A Kalokagathia szó jelentése is erre utal -,tökéletes férfiú” (Arisztotelész i.e.343) Spártában az újszülöttet édesapja karjába vette és elvitte a Leszkhé nevü helyre, ahol a vének tanácsa megvizsgálta a gyermeket. Amennyiben erősnek és életképesnek találták, megbízták az apát, hogy nevelje fel gyermekét és kijelöltek egy darab földet számára a 9000 parcellából. Amennyiben azonban nem felelt meg az elvárásoknak, a Taigetosz hegységnél, az Apothetai nevű szakadékba dobták, azzal az indoklással, hogy nem előnyös sem a gyereknek, sem az államnak, ha egy születésétől fogva sérülten életben marad. (Pukánszky és Németh,1997). Hasonlóan vélekedik a sérült emberekről Platon „A gyarlók gyermekeit és a kiválók nyomoréknak született gyermekeit pedig, ahogy illik, eltüntetik valami hozzáférhetetlen titkos zugban." és Arisztotelész is „Az újszülöttek kitevéséről vagy fölneveléséről pedig úgy intézkedjék a törvény, hogy semmiféle korcsszülöttet nem szabad fölnevelni " Ennek ellenére ókori Görög mondákban találkozhatunk Héphaisztosszal, aki maga is Isten, bár a teste nem tökéletes. Az Istenek büntetésként mérték rá a sérülést és a saját anyja veti le az Olimpüszról. Lábai csonkának nőttek, de mesterségét kimagaslóan üzi. Királyok is hozzá hordták kardjaikat, mert ő volt a leghíresebb kovács. Itt már látható, hogy a kovács sérülése ellenére a társadalom megbecsült és semmiképpen nem mellözött tagja. (Kerényi,1951)

$\mathrm{Az}$ ókori Rómában sem változott jelentősen a sérült emberek megítélése. Claudius császárról ezt írta az író „Ezt akarjátok most istenné tenni? Nézzétek meg a testét: haragjukban hozták létre az istenek." (Seneca 31) Itt is a sérülés nem más, mint az Istenek büntetése. Az ,ép testben, ép lélek” mondás (Mens sana in corpore) is ebböl a korból származik (Decimus ), bár más értelemben, mint ahogyan azt ma gondoljuk. Az író azokhoz a polgárokhoz szólt, akik felesleges ostoba imádságokkal fordultak isteneikhez. Hiszen szerinte az imádkozás célja nem lehet más, mint a testi és szellemi épség.

A középkorban úgy gondolták, hogy minden testi szépség Istentől való, a természetellenes születés pedig a gonosz müve. A csonkaság a fizikai fogyatékosság egyik legsúlyosabb formája, ezért előszeretettel alkalmazták a csonkítást büntetésként, ami visszavonhatatlan változást idézett elő az áldozatban. Az akkori európai mesevilágban is megjelennek a különböző testi változásokkal élő gonosz, vagy jóságos emberek. A boszorkányok, törpék, óriások mind mások, mint általában a mesehősök és nem feltétlenül pozitív tulajdonságokkal rendelkeznek. A „boszorkányfattyú” kifejezést használták akkor, amikor egy előkelőnek öltözött fiatalember házasságra lépett egy lánnyal, de az esküvői ruhája alól kivillant a patás 
láb. A fiatalasszony, ha az ördöggel hál, az utód a boszorkányfattyú, aki különböző rendellenességekkel jön a világra. (Ipolyi,1854) Nem kizárt, hogy ezeknek a rendellenesen fejlödő szerveknek a neveit a mai napig megtartottuk és használjuk is, mint például: farkastorok, nyúlszáj, lúdtalp, tyúkmell. Egy régi hiedelem szerint szüléskor, ha a szülő nő és a bába egy picit is elfordult, akkor ördögi erők kicserélték az egészséges újszülöttet egy sérültre. Az ilyen gyerekeket nevezték „váltott” gyereknek. A nagy mesemondó, Benedek Elek is többször ír a váltott gyerekről, pl. Váltott gyermek, Aranyhajú ifjak címü meséiben. (Benedek, 1901) A pogány magyar hitvallásban jelennek meg a táltosok, olyan emberek, aki többlet csonttal- föleg több foggal születtek. Nem csökkent, hanem többlet képességgel rendelkeztek és legföbb képességük, hogy a jövőbe láttak. Táltossá azonban csak a kiválasztottak váltak közülük, aki nem voltak méltók rá, azokat a többi táltos megnyomorította. (Diószegi, 1968)

1700-ban indult el az értelmi sérültek szervezett gondozása 1793 Párizsban a francia alkotmány 21. cikkelye határozza meg,”A köztámogatás szent adósság. A társadalom köteles eltartani szerencsétlen polgárait, akár így, akár úgy, hogy munkát szerez számukra, akár azáltal, hogy biztosítja a létfenntartásukhoz szükséges eszközöket a munkaképtelenek számára." Tehát az állam törvényeröre emelte a sérült emberek ellátását, ettől az időszaktól beszélhetünk szervezett ellátó intézményről. (Net1)

Legújabb kor: a II. Világháború hozta meg több - negatív értelemben is a fordulatot. Egyrészt emberek százezrei váltak rokkanttá, érzékszervi fogyatékossá, a háború gépezete addig páratlan mennyiségben termelte ki a sérült embereket. Másrészről a Harmadik birodalom legitimálta a csökkent értelmi képességü és sérült emberek tömegének a legyilkolását. Az árja elméletnek megfelelően csak az egészségesen fejlődött emberek maradhattak életben, a többieket a T/4-es akció kereteinek megfelelően megölték. (Net2.)

A XX. században az addigi sajnálkozó, lenéző szemléletet felváltotta az emberjogi megközelítés és az esélyegyenlőség megvalósítására irányuló törekvés. A csökkentség érzetét a kirekesztés, gúnyolódás, a másság el nem fogadása okozza, melyet maga a környezet hoz létre és termeli újra. (Kálmán és Könczei, 2002) Nagy vihart kavart fel Peter Singer professzor kijelentése Ausztráliában, mely szerint a fogyatékossággal világra jövő újszülöttek elpusztíthatók, sőt születésük utáni néhány hónapban sem tekinthetők személynek. (Zászkalacky, 1990) A XX. században azután nagyon gyorsan követték egymást a különböző nyilatkozatok és konvenciók (lásd: 1. táblázat).

1. táblázat: Nemzetközi cselekvések a fogyatékkal élök megsegítésére (forrás:Net3)

\begin{tabular}{|c|l|}
\hline \multicolumn{1}{|c|}{$\mathbf{v}$} & \multicolumn{1}{c|}{ Nemzetközi fogyatékosügyi történés } \\
\hline 1948 & $\begin{array}{l}\text { ENSZ közgyülés Emberi jogok egyetemes nyilatkozata jog: szabadság, } \\
\text { biztonság, élet, kultúra, müvelődés, vallás, véleménynyilvánítás joga }\end{array}$ \\
\hline 1960 & UNESCO Oktatásbeli diszkriminációról szóló konvenció \\
\hline 1975 & ENSZ közgyülés Nyilatkozat a fogyatékos személyek jogairól \\
\hline 1982 & ENSZ közgyülés A fogyatékos személyekre vonatkozó világprogram \\
\hline 1993 & $\begin{array}{l}\text { ENSZ közgyülés A fogyatékossággal élő emberek esélyegyenlőségének } \\
\text { alapvető szabályai (Standard Rules) }\end{array}$ \\
\hline 1994 & $\begin{array}{l}\text { UNESCO rögzítették a szalamankai ajánlást, amely kimondja, a sajátos } \\
\text { nevelési igényü gyerekek oktatása nem folyhat tovább elkülönítetten. }\end{array}$ \\
\hline 2000 & $\begin{array}{l}\text { UNESCO Dakar „Oktatást mindenkinek” Mindenkinek legyen elérhető az } \\
\text { ingyenes, alapfokú, kötelező oktatás a lakóhelyéhez közel. }\end{array}$ \\
\hline
\end{tabular}


Jelen tanulmány készítése közben elsősorban hazánkban a sajátos nevelési igényü tanulók helyzetére fókuszáltunk (2. táblázat), akik jelentős számban vesznek részt az oktatási rendszerben. Arányuk a 2015/2016 tanévben, az általános iskolákban 7,19\% (Internet 3.) és részképesség zavaraik miatt külön odafigyelést igényelnek, amelyben nem nélkülözhetik a szervezett oktatást.

2. táblázat: Hazai cselekvések törvények a sajátos nevelési igényü oktatásának szabályozására (forrás: a Szerzö)

\begin{tabular}{|c|l|}
\hline \multicolumn{1}{|c|}{$\mathbf{v}$} & \multicolumn{1}{|c|}{ Történés } \\
\hline 1993 & $\begin{array}{l}\text { Közoktatási Törvény (1993/VXXIX. törvény) A sajátos nevelési igényü } \\
\text { gyerekek oktatásának jogi kereteiröl, amely az integrációs folyamatokat } \\
\text { szabályozza. }\end{array}$ \\
\hline 2011 & $\begin{array}{l}\text { 2011. évi CXC. törvény a nemzeti köznevelésröl- SNI kategóriák } \\
\text { létrejönnek }\end{array}$ \\
\hline 2013 & $\begin{array}{l}\text { EMMI EGYMI (Egységes Gyógypedagógiai Módszertani Intézmény) Az } \\
\text { SNI tanulókat az általános iskolákban utazó gyógypedagógusok fejlesztik }\end{array}$ \\
\hline
\end{tabular}

\section{Integráció vagy inkluzív integráció?}

Az integráció az akadályozott emberek részvételének biztosítását jelenti a társadalmi folyamatokban; mint pedagógiai feladat pedig megkísérli segíteni az akadályozott és ép gyermekek tanulását didaktikai és módszertani eszközökkel. Az 1990-as években még csak integrációt használtak Magyarországon.

Integráció, amelyet a mai értelemben inkább rideg integrációnak is neveznek (Vargáné, 2006):

- a fogadó intézménynek nincs integrációs stratégiája

- a pedagógus m ódszerein nem, vagy kicsit változtat

- a problémák megoldása teljes egészében a gyógypedagógus, szülő feladata

- a gyógypedagógus a gyermekkel külön teremben foglalkozik

Ezzel szemben az inkluzív integráció (befogadás):

- az együttnevelés legmagasabb szintű formája, teljes befogadást, elfogadást s ezzel együtt az adaptív oktatást valósítja meg, maga a szemlélet beépülés a helyi tantervbe.

- átgondolt, az egyéni képességekhez, igényekhez igazodó, differenciált oktatást alkalmazó, egységes tantestületi szemlélet,

- a problémák megoldását e többségi iskola pedagógusai vállalják,

- nem húznak erős határvonalat a fogyatékos és a többi gyermek között, hiszen mindenkinek támadhatnak nehézségei a tanulás során,

- együttmüködés, közös tervezés jellemzi a gyógypedagógus és a pedagógus munkáját

- partnerségre épít,

- a gyógypedagógus elsődlegesen a pedagógusnak nyújt segítséget

- a gyermeknek nyújtott segítség az osztályon belül történik (Réthy, 2002)

Helyes irány-e az integráció? Évtizedekig müködött a szegregált oktatás, miért lett elavult, ami ellen határozottan lép fel a szakemberek többsége? A következőkben pedagógusok véleményét összegző tanulmányok lényegét igyekszem bemutatni mindkét oldalról. Az 
integráció sikeressége mindkét félen múlik. Számos tanulmány mutatja azt, hogy maguk a pedagógusok sem igazán értik, illetve elkötelezettek az integráció iránt. Egy 12 iskolát vizsgáló Dél-magyarországon pedagógusokon végzett kérdőíves kutatás során a cikk írója inkább negatív véleményeket kapott az integrációval kapcsolatosan. A pedagógusok elöítélettel viszonyulnak az SNI-tanulók felé. Nem veszik figyelembe a gyerekek oktatási igényeit, szerintük csak az alsó tagozaton müködik hatékonyan az integráció. Egy menetközben felépített, átgondolatlan „kényszerintegráció” folyik, amit a fokozatosan csökkenő gyermeklétszám miatt vállalnak az oktatási intézmények. (Majoros, 2009)

Egy Romániában végzett kutatás szerint a többségi iskolákban a többségi diákokhoz szokott tanárok az SNI tanulókkal nem megfelelően, illetve nem személyre szabottan foglalkoznak. Véleményük szerint csökkent értelmi képességüek, akik nem képesek fejlődésre. (Alois, 2012. Az ismert integráció fogalom mellett azonban megjelenik Csányi munkájában a „formális integráció” kifejezés, amelyet olyan esetekre használ a szerző, amikor a fogyatékossággal élő tanulót ugyan a jogszabályokban rögzítetteknek megfelelően integrálják, a személyre szabott segítségnyújtás azonban hiányos, vagy akár el is marad. (Csányi, 2013)

A többségi iskolák nem készültek fel a sajátos nevelési igényü gyermekek ellátására, így alakult ki az úgynevezett rideg integráció. Ez a multikulturális nevelés nélküli integráció látszólag jelent egyenlő lehetőséget biztosít minden gyerek számára azzal, hogy a többségi intézménybe felvett SNI tanulók a többi diákkal egy teremben tanulnak. Az intézmény azonban monokulturális szemléletü marad, hiszen az SNI tanulók oktatására a tanárok nem készülnek külön, nem veszik figyelembe a képességeiket, a megkülönböztetett figyelmet, egyéni bánásmódot a gyerekek nem kapják meg. Ennek oka egyrészt, hogy a pedagógus képzésben nem kapott megfelelő helyet a SNI tanulók problémájának az oktatása. A felsőoktatásba is bekerült a HEFOP 2.2.1. „Hátrányos helyzetű tanulók esélyegyenlőségének biztosítása az oktatási rendszerben" címü, 2.1. központi program egyik projektje a „Pedagógusképzési programok kifejlesztése és bevezetésének támogatása a felsőoktatási intézményekben" címmel. Ezzel együtt átalakult a felsőoktatásban a pedagógus képzés, számtalan új oktatási program elem, jelent meg azzal a céllal, hogy a hátrányos helyzetben lévő tanulókat segítse.(Net4)

Hasonló megfigyelésre jutott Földes (2003) is, aki azt állapítja meg, hogy az iskola befogadja tanulói közé az SNI-s gyerekeket, de müködésén nem változtat, a pedagógus pedig igazi felelősséget nem vállal. Az intézmény magától a gyerektől várja a beilleszkedést. Egy vizsgálat szerint Romániában az is megfigyelhető, hogy a többségi iskolák emelt szintü oktatást kínálnak valamilyen tantárgyból. Az ilyen oktatást nyújtó intézményekben általában a magasabb társadalmi státusú , odafigyelöbb szülök gyerekei kerülnek be ezekre az évfolyamokra. Az ilyen „elit” osztályokba járó gyerekek, szülök, sőt a tanárok is kevésbé tolerálják az együttnevelést, mint a más osztályokban, ahogy azt leírta Alois (2010) Az ilyen tagozatokon a megfelelö képességek hiánya miatt szórványos az SNI tanulók létszáma. Egy másik lehetőség éppen ennek a programnak az ellenkező változata, mely szerint az SNI-s gyerekek számára indítanak speciális osztályokat képességeiknek megfelelően. Monika T. (2013) megállapítása szerint a cseh oktatási rendszer a mai napig inkább kirekesztő, a tanárok jellemzően negatívan állnak az SNI tanulókhoz. Véleményük szerint az SNI-tanulók számtalan pedagógiai problémát okoznak, nincsen idő és elegendő pénz a fejlesztésükre állításuk szerint. (Egy Indonéziában végzett vizsgálat szerint Kurniawati és társai (2012) azt tapasztalták, hogy a megkérdezett tanárok alapvetően pozitívan állnak az integráció kérdéséhez. A folyamat sikerességének szerintük is egyik kulcsa a tanárok hozzáállása az SNI-tanulókhoz, különösen akkor, ha a pedagógusoknak már volt előzetes tapasztalatuk a tanulási nehézségekkel küzdő tanulókkal, illetve vettek részt olyan képzésen, amelynek célja az ő speciális oktatásuk. Hasonló megfigyelésre jutott Némethné (2009) is egy hazai kutatás kapcsán. Hasonlóan vélekedik Unianu (2013), aki szerint törvénykezési szint önmagában 
kevés, a pedagógus az egyik kulcsszereplö, véleménye szerint a tanárok legfontosabb feladata, hogy meghatározzák az egyéni fejlesztési tervet tanítványaik részére.

De nem csak a pedagógusok, hanem az őket képző intézmények, illetve az iskolák fenntartói is beleszólhatnak az integrációs folyamatok alakulásába. Ilyen értelemben a társadalmi folyamatok szervezői is befolyásolhatják döntéseikkel az integráció sikerességét. Egy Romániában végzett felmérés bizonyítja, hogy az általános iskolák tanárai nem kaptak megfelelő képzést és fel-készületlenek az SNI-tanulókkal történő oktatásra, nem megfelelő a kommunikáció az utazó gyógypedagógus és a szaktanárok között. Állami szinten jellemző a lassú átalakítási folyamat, mely során a többségi iskolákat befogadóvá kívánják tenni. (Alois, 2011) Az oktató-nevelő munka önmagában kevés. Az oktatási tevékenységek szervezési feladatai legalább olyan fontosak, mint maga a pedagógiai munka. Egy Törökországban végzett vizsgálat során megállapították (Ayten, 2009), hogy a tradicionális módszerekkel történő oktatás önmagában nem elegendő, ezért a tanárképző intézetekben külön kurzusokat indítottak az oktatás szervezésével kapcsolatosan. Csongor Anna véleménye szerint „A helyes valamilyen erkölcsi értelemben természetesen az lenne, ha minden gyerek nemzetre, fajra, nemre és felekezetre való tekintet nélkül egyenlő minőségü oktatási feltételekben részesülne. De ez sehol sincs teljesen így. Az oktatási rendszer tükrözi a társadalmi elkülönülés/különállás mértékét. És ez a különállás nem oldható meg az iskola-rendszerben önmagában." (Csongor, 1991, 5.o.)

Egy igen alapos kutatás eredményeképpen állapítják meg a szerzők, hogy a szegregáció inkább negatív társadalmi folyamatokat indít el. Romlik a tanulók önértékelése és társaihoz való viszonya is, amik túlmutatnak az iskolai teljesítményükön. Az integrációval viszont csökkenne az előítéletesség és a távolságtartás. (Kertesi és Kézdi 2009) A születési számok csökkenése következtében fellépö tanulóhiányt az általános iskolák is megsínylették. Az egyre csökkenő tanulólétszám miatt csoport,- és intézmény összevonások váltak szükségszerüvé. Az intézmény-vezetőknek reagálniuk kellett a kialakult helyzetre a kettős nyomásban, amelyet részben a fenntartó, részben a saját kollégáik hoztak létre. Az oktatási feladatokon kívül valódi versenyhelyzet alakult ki a fogyasztókért, akik nem mások, mint a tanulók és szüleik lettek. Alaposan meg kellett tervezniük, hogy milyenek a kielégítésre vágyó szülöi és társadalmi igények. Az iskola életének összhangban kell lennie az országos és a helyi oktatáspolitikával. (Balázs és Szabó 2009)

Az állami irányítás az 1993. évi Közoktatási törvény egyrészt elöírja az inklúzív integrációt, másrészről teret ad az egyes tagozatok beindításának. Ennek megfelelően kétféle eredmény születik: létrejönnek az integrált és a szegregált osztályközösségek is. Az általános iskolák vezetőinek egyik negatív példáját írja le Bánfalvy (2009), aki a fogyatékkal élő iskolás gyerekeket vizsgálta. Megállapításai szerint a demográfiai dagály idején a sérült tanulókat elkülönült intézményekben kívánták oktatni, demográfiai apály idején, pedig az addig normál tantervü iskolák is befogadták őket tanulóik soraiba. Alapelv, hogy a társadalomnak küzdenie kell a rasszizmus, szociális szegregáció, faji, nemi megkülönböztetés, hátrányos helyzetűek, vagy bármilyen mássággal élö emberek megkülönböztetése ellen. Az oktatási folyamatban az az érdekes helyzet áll elő, hogy pozitív diszkriminációt alkalmaznak tanulási nehézségekkel küzdő tanulókkal szemben, pontosan abból a célból, hogy így tegyék őket egyenlővé a többiekkel. (Luciana, 2012) Egy magyar általános iskolában végzett kérdőíves attitüd vizsgálat során (Pongrácz, 2003) arra kereste a választ, hogyan viszonyulnak az adott többségi általános iskola felső tagozatán tanulók a fogyatékossággal élő társaikhoz, illetve milyen tényezők, ismeretek befolyásolják beállítódásukat. Egy nemzetközileg elfogadott attitüdöt vizsgáló skálát $(\mathrm{CATCH})$ használt. Eredményképpen azt tapasztalta, hogy a következö tényezők jeleztek pozitív attitüdöt: fiatalabb életkor, a magasabb önértékelés, közelebbi kapcsolat a fogyatékossággal élő gyermekkel, a jobb életminőség. Viszont a válaszadók neme és a fogyatékossággal élő emberekről való előzetes ismeret nem befolyásolták az attitüdöt. 
Az általános iskoláknak kötelessége felvennie a körzetükben élő gyerekeket, amely vonatkozik a SNI-s tanulókra is. A kötelesség azt is jelenti, hogy a lakóhelyükhöz legközelebb eső iskolába kell a gyerekeket felvenni. Ennek ellenére eltérés van az egyes általános iskolákba járó SNI-s gyerekek létszámában, amely nem pusztán a lakhely szerinti megoszlást mutatja. Az oktatási intézmények pedagógiai programját az iskola vezetősége az ott dolgozó pedagógusokkal együttműködve dolgozza ki, ezzel lehetőséget teremtenek a beiratkozni vágyó diákok összetételének meghatározására. a látszólag nehéz feladatot az iskolák többféleképpen valósíthatják meg. Az egyik megoldás a különböző tagozatok (nyelvi, testnevelés) beindítása, melybe jobbára csak az érdeklődő szülők íratják be gyerekeiket $\mathrm{Az}$ ilyen intézményekre jellemző hogy alapítványi, esetleg önkormányzati fenntartással müködnek és sokszor komoly gondokat okoz müködtetésük. Kerülő (2008) esettanulmánya bemutat egy Nyíregyházán évek óta szegregált formában müködő általános iskolát, ahol elég volt egy önkormányzati döntés ahhoz, hogy azt bezárják. A döntés alapja a szalamankai ajánlás (1994), amely kimondja, hogy az SNI-tanulók oktatása nem fejlődhet tovább szegregált formában.

\section{Korlátozások}

Jelen tanulmány elkészítése 21 pedagógiai kutatás eredményét összegzi, amely az SNI tanulók integrációjának helyzetét vizsgálja.

\section{Konklúziók}

Alapvető cél a társadalmi életben , így az oktatásban is az egyenlő esélyek megteremtése, a speciális oktatási igényekkel rendelkező gyermekek együttnevelése és a diszkrimináció megszüntetése. Ma sehol a világon, így Magyarországon sem létezik olyan szakmai fórum, amely támogatná a szegregált oktatást, de ennek ellenére sokan úgy vélik, hogy a speciális szükségletekkel rendelkező gyermek oktatása jobban megoldható lenne az általános iskolák keretein kívül (Kende, 2004). Az integráció nem kérdés, hanem egy megoldandó feladat. Minden általános és középiskolában a mindnekori köznevelési és/vagy -oktatási törvény szabályozza a fogyatékkal élő tanulók integrációját. A sikeresség azonban nem a szabályozókon, hanem az adott iskola vezetésén, az ott tanító tanárok hozzáállásán, illetve az érintett gyerekek szülein múlik. A mai napig folyik a vita a szakértők között a szegregáltintegrált oktatás tekintetében. Mindkét oldalon alapos kutatásokkal alátámasztott érvek és ellenérvek sorakoznak.

Jelen tanulmány célja az volt, hogy irodalmi áttekintés alapján bemutassa a fogyatékkal élők elfogadásának a történetét, illetve áttekintsen 21 tanulmányt a szegregáció-integráció témakörében. Összefoglalva megállapíthatjuk, hogy még további vizsgálatok szükségesek ahhoz, hogy biztosan kijelenthessük melyik módszer a helyesebb. amelyek éveket-évtizedeket vehetnek igénybe. Másik kérdés, milyen típusú sérüléssel rendelkező gyerekeknél lehet alkalmazni a szegregációt, vagy az integrációt. Az emberiség történelme során folyamatosan éltek egészséges társaikkal együtt a különböző testi fogyatékkal élő emberek. Ez valószínűen a jövőben sem fog változni. Maguk a sérült emberek is szeretnének változtatni saját állapotukon, hogy ne különbözzenek ép társaiktól. Remélhetöleg a technika fejlődése nagyon sokuk állapotát képes lesz megváltoztatni, pl. tökéletesen müködő protézisek, plasztikai mütétek segítségével. De addig is inkább a társadalmi környezetüknek szükséges úgy változni, hogy ne érezzék másságukat. Szerencsére (illetve remélhetőleg) jelenleg az érintett tanulók Magyarországon mindenhol maximális segítséget kapnak. A jó szándék tehát adott. Kérdés, hogy melyik oktatási forma alkalmazásával segítenénk őket jobban? Bárdonicsekné 
(2012) szerint sem a szélsőséges szegregáció, sem pedig az „integráció mindenáron” elve nem követhető forma, a kettő között kell megtalálni az arany középutat.

\section{Irodalom}

Arisztotelész: Politika. Gondolat könyvkiadó 1984, ISBN: 9632813650

Bánfalvy Cs. (2009) A fogyatékos emberek iskolai integrációjáról. Esély 2009/2 3-15.o.

Benedek E. (1901) Magyar mese és mondavilág. I-III. kötet. Budapest, Téka és Móra kiadó 1988, ISBN: 9637357289

Castelli, L. (2012) Equity in education: a general overview. Procedia Social and Behavioral Sciences 69 (2012) 2243-2250p.

Csányi Y. (2013) Integráció/inklúzió és a szakvéleményezés összefüggései.Gyógypedagógiai Szemle 2013 - XLI. évfolyam, 3.szám 165-173.o.

Csongor A. (1991): Szegregáció az általános iskolában. Oktatáskutató Intézet, Budapest ISSN_08654409

Decimus (kb.100) Szatírák. In Persius - Iuvenalis: Szatírák. Európa kiadó 1977

Diószegi V. (1967) A pogány magyarok hitvilága. Budapest, Akadémia kiadó 1983,ISBN: 9630535599

Fekete I. (1959) Téli berek Móra könyvkiadó ISBN: 9789631193312

Földes P. (2003) Speciális szükséglet vagy fogyatékosság? A befogadó pedagógia helye a magyar közoktatásban.Beszélgetés Dr. Csányi Yvonne-nal.Új Pedagógiai szemle, 1. 6773.0.

Ghergut, A. (2010) Analysis of inclusive education in Romania Procedia Social and Behavioral Sciences 5 (2010) 711-715p.

Ghergut, A.(2011) National policies on education and strategies for inclusion; case studyRomania. Procedia Social and Behavioral Sciences 29 (2011) 1693-1700p.

Ghergut, A.(2012) Inclusive education versus special education on the Romanian education system. Procedia Social and Behavioral Sciences 46 (2012) 199-203p.

Ipolyi A. (1854) Magyar Mythológia. Pest Heckenast

Kákosy L. és Varga E. (1970) Egy évezred a Nílus völgyében. Gondolatkiadó 1970 ISBN: 2050210093147

Kálmán Zs., Könczei Gy. (2002): A Taigetosztól az esélyegyenlöségig. Osiris, Budapest, 2002. ISBN: 9789633893111

Kende A. (2004) Együtt vagy külön? A szegregált iskolarendszer és a speciális oktatási szükségletek. Iskolakultúra 2004/1. 3-13.o.

Kerényi K. (1951) Görög mitológia. Budapest, Gondolat kiadó 1977 ISBN: 9632803760

Kertesi G. és Kézdi G. (2009) Általános iskolai szegregáció Magyarországon az ezredforduló után. Közgazdasági Szemle LVI.2009.november 959-1000 o.

Kerülő J. ((2008) Az integráció és a szegregáció kérdése egy iskolabezárás kapcsán. Oktatáskutató és fejlesztő intézet könyvtára Új pedagógiai szemle2008.01. 12-28.o.

Kurniawati, F. és tsai (2012) Empirical study on primary school teacher's attitudes towards inclusive education in Jakarta, Indonesia Procedia Social and Behavioral Sciences 69 (2012) 1430-1436p.

Majoros A. (2009) Semmirekellők, naplopók... avagy az iskolai integráció egy délmagyarországi kistérségben Gyógypedagógiai Szemle 2009/4 239-252. o.

Net1Letöltés: 2016.06.27. Web: http://www.tankonyvtar.hu/en/tartalom/tkt/alkotmanyjog/ch08s03.html.pdf).

Net2Letöltés: 2016.06.26.) (Web: http://www.tankonyvtar.hu/hu/tartalom/tamop425/2011_0001_536_MagyarNyelv/ch28.ht ml.pdf). 
Net3Letöltés: 2016.06.30. Web:

http://www.tankonyvtar.hu/hu/tartalom/tamop425/2011_0001_520_a_taigetosztol/ch03s07. html.pdf).

Net4Letöltés: 2016.07.19. Web: http://www.educatio.hu/bin/content/tamop311/download/tamop_311/2piller_tanulmanyok/ 09_pedagoguskepzes_szerepenek_meghatarozasa/9_TANU_1.pdf).

Némethné Tóth Á. (2009) Tanári attitüdök és inkluzív nevelés Magyar Pedagógia109.évf. 2.szám 105-120. o.

Platón: Az állam. Gondolat, Budapest 1988. 126. o. ISBN: 9632827201

Pongrácz K. (2013) Többségi általános iskolások sajátos nevelési igényü gyermekekkel szembeni attitüdjének vizsgálata. Gyógypedagógiai Szemle 2013 - XLI. évfolyam, 3.szám. 197-207.o.

Pukánszky B. és Németh A. (1998) Neveléstörténet. Nemzeti Tankönyvkiadó Rt ,ISBN: 9631888169

Réthy E. (2002).A speciális szükségletü gyermekek nevelése, oktatása Európában. Magyar Pedagógia ,102.( 3). 281-300.

Saban, A. (2009) Management of teaching and class control. Procedia Social and Behavioral Sciences 1 (2009) 2111-2116p.

Seneca, L. (31) Apocolocyntosis. Magyar Helikon, Budapest 1963. 10. o. ISBN: 2050240030235

Tannenbergerová, M. (2013) Equality in educational system as a challenge for future teachers. Procedia Social and Behavioral Sciences 93 (2013) 549- 554 p.

Unianu, E. (2013) Teacher's perception, knowledge and behaviour in inclusive education Procedia Social and Behavioral Sciences 84 (2013) 1237-1241 p. 